DOI: 10.36910/6775-2524-0560-2020-40-01

УДК: 004.5

Булатецький Віталій Вікторович, канд. фіз.-мат. наук, доцент

https://orcid.org/0000-0002-9883-4550

Булатецька Леся Віталіївна, канд. фіз.-мат. наук, доцент

https://orcid.org/0000-0002-7202-826X

Павленко Юлія Степанівна, старший викладач

https://orcid.org/0000-0002-4065-045X

Східноєвропейський національний університет імені Лесі Українки, м. Луцьк, Україна

\title{
ОРГАНІЗАЦІЯ РОБОЧОГО МІСЦЯ ВИКЛАДАЧА ЗАСОБАМИ ОПЕРАЦІЙНОЇ СИСТЕМИ ТА ХМАРНИХ СЕРВICIB
}

В. В. Булатецький, Л. В. Булатецька, Ю. С. Павленко. Організація робочого місця викладача засобами операційної системи та хмарних сервісів. В роботі запропоновано спосіб організації персонального робочого місця викладача. При цьому враховувались можливості типового користувача без особливих навиків роботи 3 персональним комп'ютером. Перевага поданих рекомендацій саме у можливості організації робочого місця за допомогою типових поширених програмних засобів однією особою без залучення додаткових спеціалізованих корпоративних сервісів та спеціалізованих програмних рішень.

Ключові слова: автоматизоване місце викладача, операційна система, хмарне сховище, електронний журнал, сайт викладача.

В. В. Булатецкий, Л. В. Булатецкая, Ю. С. Павленко. Организация рабочего места преподавателя средствами операционной системы и облачных сервисов. В работе предложен способ организации персонального рабочего места преподавателя. При этом учитывались возможности типичного пользователя без особых навыков работы с персональным компьютером. Преимущество представленных рекомендаций именно в возможности организации рабочего места с помощью типовых распространенных программных средств одним лицом без привлечения дополнительных специализированных корпоративных сервисов и специализированных программных решений.

Ключевые слова: автоматизированное место преподавателя, операционная система, облачное хранилище, электронный журнал, сайт преподавателя.

V. V. Bulatetskyi, L.V Bulatetska. Yu. S. Pavlenko. Organization of the teacher's workplace by means of the operating system and cloud services. The method of organization of the teacher 's personal workplace is offered in the work. It was taken into account the capabilities of the typical user without special PC skills. The advantage of the given recommendations is in the possibility of organizing the workplace with the help of standard distributed software by one person without the involvement of additional specialized corporate services and specialized software solutions.

Keywords: automated teacher location, operating system, cloud storage, electronic journal, teacher's site.

Постановка проблеми та аналіз досліджень. В сучасних умовах організації навчального процесу у закладах вищої освіти і не тільки, кожен викладач рано чи пізно стикається 3 необхідністю організації навчальних матеріалів курсів, які він викладає, обліку користувачів (студентів), ведення оцінювання (у вигляді електронних журналів) та іншої документації тощо [1-4]. Існує велика кількість розробок, які сприяють полегшенню вирішення такої проблеми, проте ідеальної системи не існує. Не всі вони є зручними для використання, не всі здатні вирішити поставлені завдання, не всі $є$ легким у вивченні для подальшого ефективного використання, або ж доступними для переважної більшості користувачів, навики роботи яких з сучасною комп'ютерною технікою досить посередні. Проте переважна більшість користувачів мають доступ до типових апаратних та програмних засобів повсякденного використання, вдало об'єднавши які, можна $з$ успіхом полегшити свою професійну діяльність, автоматизувавши свою роботу із широким спектром задач.

Зокрема, більшість (практично усі) викладачі мають:

- оступопольної мережі Internet;

- $\quad$ персональну обчислювальну систему у вигляді ноутбуків (в гіршому випадку

ПК) з OC Windows не нижче Windows 7, а найчастіше - це Windows 10;

MS Office не нижче версії 2010, а найчастіше 2013, 2016;

найпростіші навики роботи з офісними додатками;

практично усі викладачі мають обліковий запис Google;

практично усі викладачі без проблем можуть створити обліковий запис

Microsoft (onedrive.live.com) і отримати доступ до усіх пов'язаних з ними можливостей, як то

власна проста сторінка, хмарне сховище, онлайн офісні додатки, тощо.

Набір таких засобів дозволить суттєво прискорити та оптимізувати власну професійну діяльність, особливо в сучасних умовах, пов'язаних з введенням дистанційного навчання. Деякі заклади вищої освіти розробляють цілі автоматизовані системи управління навчальним закладом $[5,6]$. Перевага

( В. В. Булатецький, Л. В. Булатецька, Ю. С. Павленко. 
таких розробок полягає в тому, що вони адаптовані до навчального процесу окремого конкретного навчального закладу, де врахована його специфіка, але знову ж не врахована специфіка викладання та оцінювання для окремої дисципліни. Звісно, для викладання курсів варто було б використати якесь готове рішення, наприклад систему Moodle або Google Classroom, проте складність може виникнути як на етапі розгортання та доступу, так і з опановуванням навичок роботи із ним, що досить важко для пересічного користувача (викладача), особливо, старшого покоління.

Метою роботи є дослідження можливості використання типового програмного забезпечення загального призначення та формулювання базових рекомендацій для організації персонального робочого місця викладача, враховуючи обмежені можливості, знання та навики однієї, непідготовленої спеціально особи.

Виклад основного матеріалу й обгрунтування отриманих результатів дослідження.

Перерахуємо перелік типових задач, які постають перед викладачем закладів вищої освіти:

- розміщення матеріалів курсів (тексти лекцій, завдання до практичних, лабораторних робіт, допоміжне програмне забезпечення для курсу тощо);

- надання онлайн доступу до матеріалів курсів та розмежування прав для викладача та студента;

- ведення обліку та оцінювання роботи студентів у формі, близькій до журналу академічних груп, $з$ онлайн доступом для студентів;

- оперативне редагування викладачем матеріалів курсів та електронних журналів академічних груп;

- оперативна взаємодія зі студентами 3 метою контролю їх діяльності, інформування та консультування.

Тобто нам потрібне буде єдине середовище роботи для викладача (власне це сама OC Windows), сайт викладача, який зможуть використовувати студенти для доступу до ресурсів курсів (обираємо sites.google.com, як найпростіший), та хмарні сховища для електронних академічних журналів, документації (OneDrive від 5GB за замовчуванням безкоштовно), сховище для матеріалів курсів (GoogleDisk - 15GB безкоштовно) та додаткове сховище для дублювання та резервного копіювання матеріалів курсів (Mega.nz до 50GB безкоштовно).

Звичайно, розпочати потрібно з операційної системи (вважатимемо найтиповішою Windows 10). Зокрема, необхідно організувати вхід через обліковий запис Microsoft (який можна створити в процесі переходу 3 локального облікового запису), що суттєво оптимізує подальшу роботу 3 офісними додатками та хмарним сховищем від Microsoft. При першому вході варто налаштувати штатний додаток OneDrive: обрати папки для синхронізації 3 локальними папками, де розміщуватимуться електронні журнали та інша супровідна документація. Це полегшить оперативне редагування таких файлів через їх відкриття через звичайний провідник і далі у локальних офісних застосунках, таких як MsWord, MsExcel та ін. (можливе використання також Microsoft 365, проте робота через браузер менш комфортна, ніж з локальним застосунком). Звичайно, можна скористатись вільними офісними рішеннями (Libre Office, Open Office тощо), проте деякі функції електронних журналів та документів важче, або взагалі неможливо, буде реалізувати, а взаємодія з операційною системою ускладниться і суттєво гальмуватиметься.

Зупинимось на електронних журналах академічних груп детальніше. Крім висвітлення оцінок в електронній формі $є$ потреба забезпечення можливості автоматичного розрахунку підсумкових семестрових показників успішності, формування заліково-екзаменаційних відомостей та ін. Недоліками існуючих електронних журналів $\epsilon$ те, що більшість їх $є$ платними, а також не врахована специфіка оцінювання для конкретного закладу вищої освіти та для конкретної дисципліни $[3,4]$. Зрозуміло, що найпростіше використати електронні таблиці Ms Excel, відформатувавши їх у вигляді реального паперового журналу. Надалі у сховищі OneDrive можна надати доступ (отримавши посилання) до таких файлів для перегляду студентами, розмістивши посилання на сайті викладача (sites.google.com) [7]. Використання таких електронних журналів надає швидкий доступ до результатів успішності студенту та викладачу, дозволяє контролювати оцінки студентів та швидко виявляти студентів 3 академічною заборгованістю. Крім того, при такій організації, ніхто крім викладача не має права змінити поточну успішність студента, що забезпечує абсолютну прозорість навчального процесу. Сформувати електронну таблицю кожен викладач може в міру своїх знань та навиків роботи у табличному процесорі. Проте окрім звичайного списку студентів, оцінок, дат та тем занять можна реалізувати наступне:

- автоматичний підрахунок балів поточного контролю та контрольного оцінювання;

- продовження рядків списків, включивши індексацію балів (щоб не мати справу з дробовими оцінками в 100 бальній, або будь-якій іншій системі); 
- реалізувати різноманітні умовні комірки - як то зарахування-незарахування на залік, оцінювання іспиту по запитанням та їх автоматичне сумування;

- конвертацію балів в систему ESTC, переспрямування на перездачу, комісію;

- автоматичне приховування рядків із студентами, які вже отримали залік (іспит) для спрощення роботи із студентами, які залишились;

- генерування екзаменаційної, чи залікової відомості з автоматичним перенесенням оцінок 3 електронного журналу;

кольорове маркування та індивідуальне форматування комірок для наочності шляхом умовного форматування (рис. 1, [7]).

Не все це можна реалізувати засобами Libre або OpenOffice, а іноді відкриття журналів у цих пакетах може нівелювати деякі із цих функцій і частково зіпсувати сам журнал.

У сховищі OneDrive варто розміщувати невеликі за об'ємом файли, такі як електронні журнали, списки, перелік запитань до іспитів, розклади тощо, оскільки це сховище постійно синхронізуватиметься, і при розміщенні масивних файлів (такі, які зустрічатимуться у матеріалах курсів), постійно гальмуватиме систему та канал зв'язку. До усіх цих файлів можна отримати посилання з розмежуванням доступу і розмістити їх пізніше на сайті викладача для використання студентами.

Інші сховища (GoogleDisk, Mega.nz), які мають суттєво більший об'єм, можна використати для розміщення матеріалів курсів, також отримати посилання та розмістити їх на сайті викладача для використання студентами. Проте такі сховища не варто синхронізувати, адже вони змінюватимуться рідко, засоби їх синхронізації $є$ сторонніми для операційної системи та синхронізація масивних файлів може бути досить тривалою. Простіше періодично, не під час проведення занять, оновлювати матеріали курсів у ручному режимі через сервіси типу FTP, WebDAV або браузер.

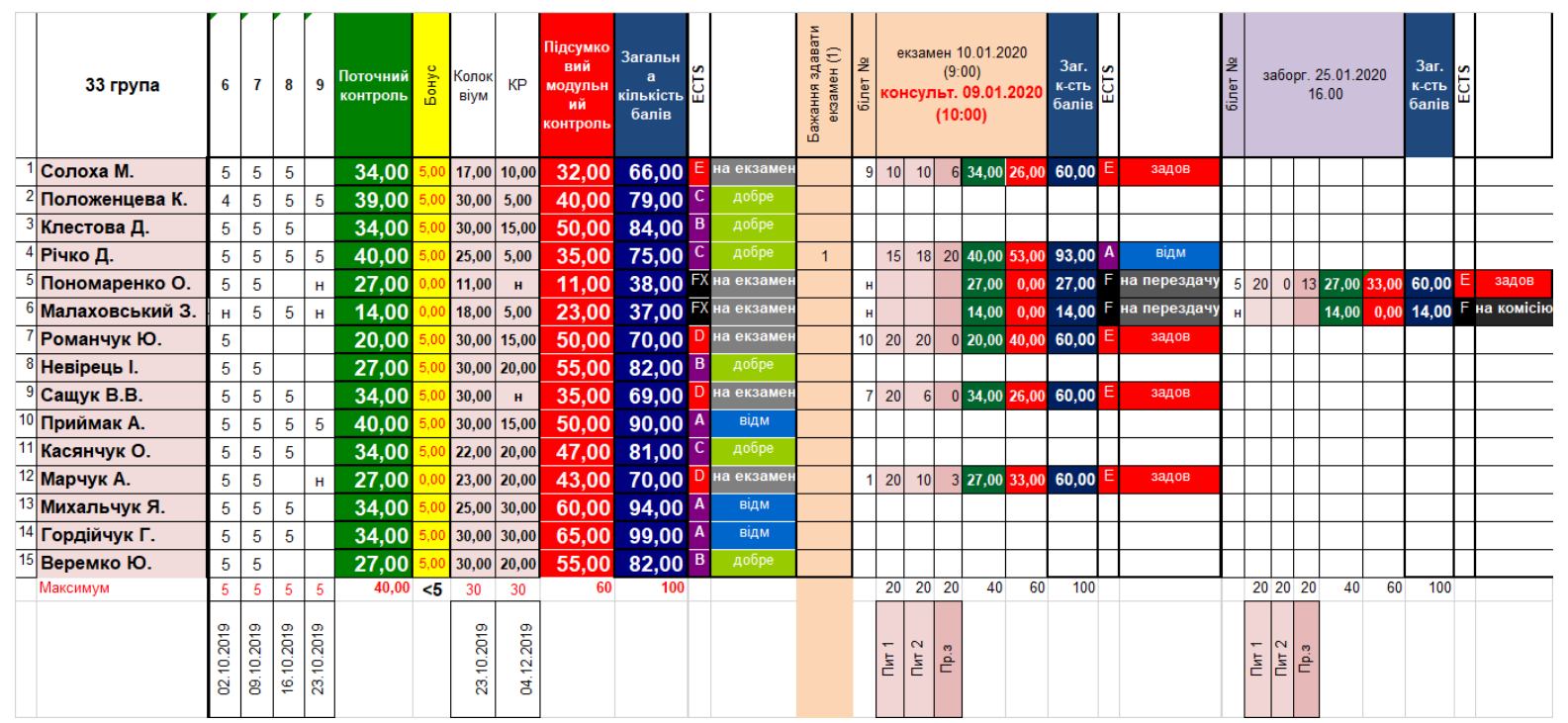

Рис.1. Фрагмент електронного журналу семестрової успішності студентів, розроблений засобами Ms Excel

Конструктор сайту викладача (sites.google.com) повинен мати інтуїтивний інтерфейс, де можна обрати відповідне оформлення, структуру розділів, розмістити корисну інформацію та посилання, не маючи особливих навичок веб-програмування [7]. Створивши 3 його допомогою сайт, можна створити систему викладач-студент (рис. 2).

Фактично викладачеві у процесі роботи достатньо використовувати лише:

- операційну систему Windows (7, 8, 8.1, в ідеальному випадку - 10);

- OneDrive;

- Браузер (бажано Edge, IE);

- $\quad$ Ms Office 2007-2019.

Студент в той же час може використовувати будь-яку операційну систему (Linux, Windows, Android) 3 Internet-браузером.

Більш детально взаємодія складових системи зображена на рис. 3. Зокрема, сама операційна система здатна звертатись до OneDrive, як безпосередньо через додаток, так і через браузер чи 
застосунки Ms Office (залежно від того з якими файлами працює викладач: журнали, файли завдань, документація чи списки). Iз сховищами Mega та GoogleDisk робота ведеться викладачем через браузер, хоча можливий варіант і з використанням сторонніх засобів. Викладач редагує свій сайт, теж через браузер. Сам сайт підвантажує матеріали 3 хмар, а студент отримує посилання на хмарні ресурси через сайт i, в залежності від потреб, може отримувати доступ на читання, або і на запис у хмарне сховище напряму, оминаючи сайт. Безпосередньо з операційною системою викладача студент не працює.

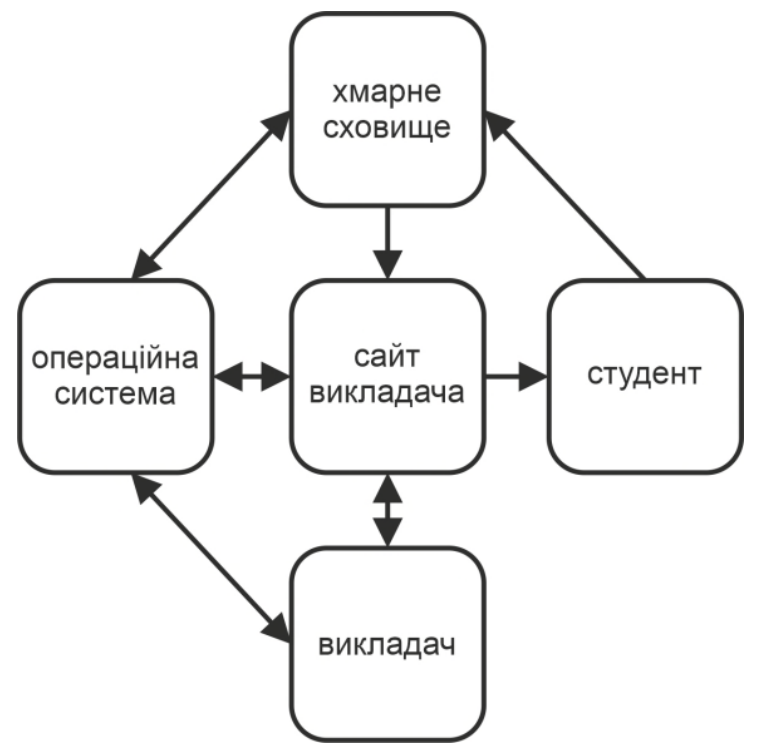

Рис. 2. Загальна схема взаємодії викладача та студента.

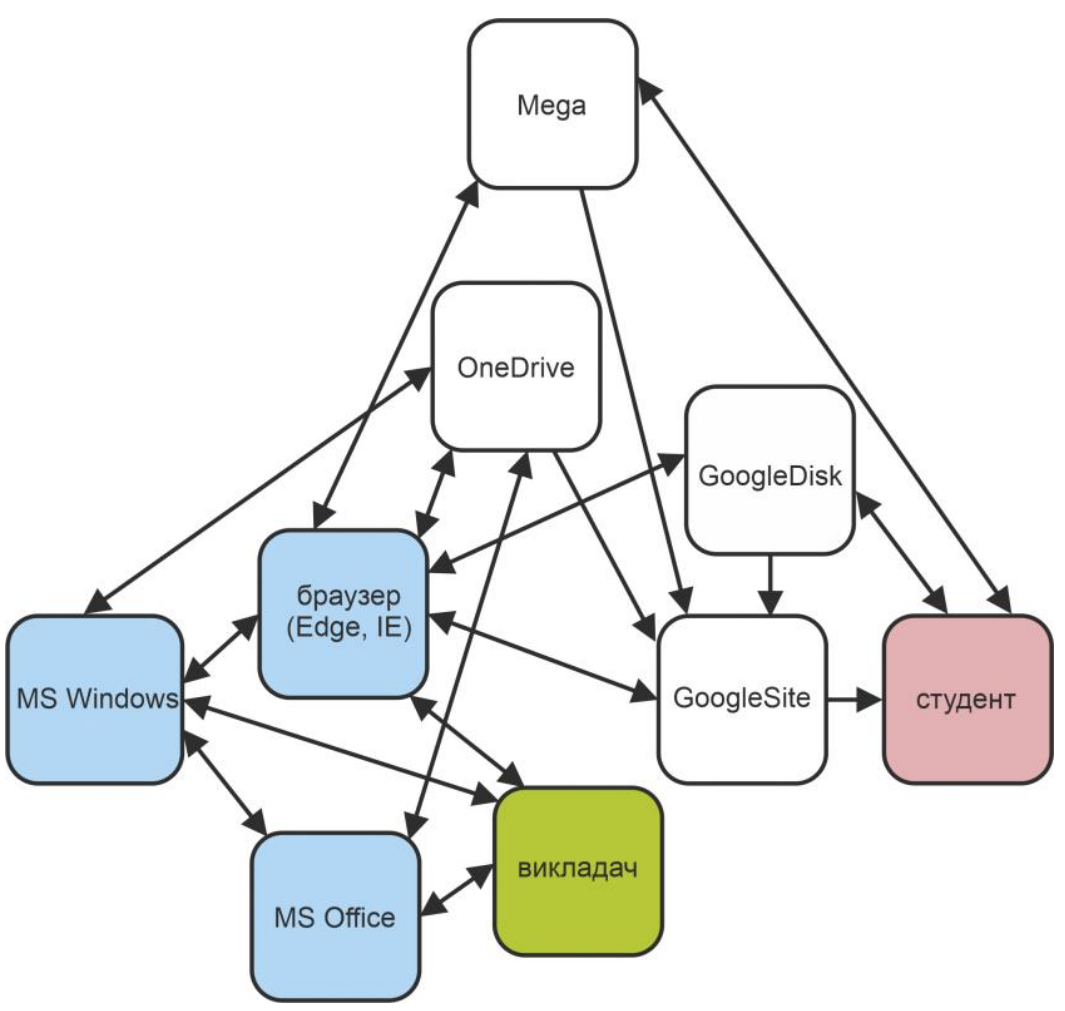

Рис. 3. Детальна взаємодія компонентів системи.

В процесі викладання курсів часто виникає необхідність проведення контрольних заходів у вигляді повернення викладачеві файлових завдань, що легко організувати на базі хмарних сховищ, створивши папку з доступом для запису як для усіх студентів, так і для кожного студента окремо, організувавши додаткову розсилку посилань через сторонні месенджери, пошту тощо, проте це 
окрема задача, форма вирішення якої залежить від кожного конкретного викладача та предмету, який він викладає. Контрольні заходи можуть включати в себе тести, які теж можна організувати різними способами, наприклад, за допомогою Google Forms.

Висновки та перспективи подальшого дослідження. Перевага вище описаного методу організації робочого місця викладача у тому, що його розгортання під силу одній особі, яка володіє обмеженими навичками роботи 3 персональним комп'ютером і при цьому використовує типові програмні засоби, які присутні на комп'ютерах практично у кожного користувача. Тобто, у результаті отримаємо саме персональне робоче місце викладача, незалежне від інших користувачів, додаткових корпоративних сервісів тощо.

Існують більш ефективні засоби організації робочих місць викладачів, інтегровані у інформаційну систему конкретних закладів вищої освіти, наприклад система Moodle, елементи якої без проблем можна використати при організації робочого місця викладача, проте їх розгортання однією особою (викладачем) здійснити суттєво складніше, та і кваліфікація його повинна бути вищою. При цьому, можливо, необхідно буде скористатись додатковим спеціалізованим програмним забезпеченням, отримати доступ до корпоративних ресурсів, або їх створити 3 організацією розмежування прав доступу тощо.

\section{Список бібліографічного опису}

1. Кузьміна Н. М. Автоматизоване робоче місце майбутнього вчителя економіки / Н. М. Кузьміна, О. В. Струтинська. Науковий часопис НПУ імені М. П. Драгоманова. Серія 2 : Комп’ютерно-оріснтовані системи навчання. - 2011. - № 10. - C. 45-58.

2. Ганашок А. I. Створення автоматизованого робочого місця вчителя інформатики засобами офісних програм [Електронний ресурс] / А. І. Ганашок. Інформаційні технології і засоби навчання - 2012. - Т. 32, № 8. - С. 46-51. Режим доступу до журналу : http://www.journal.iitta.gov.ua.

3. Діденко О. В. Електронний журнал обліку успішності слухачів (курсантів, студентів) як засіб раціоналізації навчально-виховного процесу [Електронний ресурс] / О. В. Діденко, Д. А. Купрієнко. Інформаційні технології і засоби навчання. - 2015. - Т. 47, №. 3. - С. 110-123. Режим доступу до журналу : http://www.journal.iitta.gov.ua.

4. Купрієнко Д. А. Електронний журнал обліку успішності слухачів (курсантів, студентів) Національної академії Державної прикордонної служби України - інструмент раціоналізації навчально-виховного процесу [Електронний ресурс] / Д. А. Купрієнко. Вісник Національної акаідемії Державної прикордонної служби України : електрон. наук. фах. вид. / гол. ред. Грязнов I. О. - 2012. - № 3. - Режим доступу : http://www.nbuv.gov.ua/ejournals/Vnadps/2012_3/12kdanvp.pdf.

5. Триус Ю.В. Інформаційно-аналітична система управління навчальним процесом ВНЗ [Електронный ресурс] / Ю.В.Триус, І.В.Стеценко, І.В.Герасименко [та ін.]. Інформаційні технології в освіті. - 2011. - № 9. - С. 40-49. Режим доступу : http://ite.kspu.edu/issue-9/p-40-49

6. Гломозда Д. К. Про один підхід до організації взаємодії між автоматизованою системою управління навчальним закладом та системою керування навчанням / [Електронний ресурс] / Д. К. Гломозда . Наукові записки НаУКМА. Комп'ютерні науки. - 2010. - Т. 112. - С. 30-33. - Режим доступу : http://nbuv.gov.ua/UJRN/NaUKMAkn_2010_112_9

7. VV\&LV(dev) - Google Sites [Електронный ресурc]. - Режим доступу : https://sites.google.com/site/bulatetsky.

\section{References}

1. Kuzmina N. M., Strutynska O. V. Automated workplace of the future teacher of economics / N. M. Kuzmina, O. V. Strutynska. Scientific journal of NPU named after MP Drahomanov : collection. Science. - Kyiv. Series 2, Computer-based learning systems. - 2011. - Issue 10. - P. 45-58.

2. Ganashok A. I. Creation of automated work places of informatics teacher by means of office applications [online] / A. I. Ganashok. Information Technologies and Learning Tools - 2012. - Vol. 32, Issue 8. - P. 46-51. - Available from : http://www.journal.iitta.gov.ua

3. Didenko O. V. Electronic journal to record students' progress (cadets, students) as a means of rationalization of the educational process [online] / O. V. Didenko, D. A. Kupriyenko. Information Technologies and Learning Tools - 2015. - Vol. 47 , Issue 3. - P. 110-123. Available from: http://www.journal.iitta.gov.ua.

4. Kupriyenko D. A. Electronic Journal of the success of students (cadets, students) of the National Academy of the State Border Guard Service of Ukraine - a tool rationalization of the educational process [online] / D. A. Kupriyenko. Bulletin of the National Academy of the State Border Guard Service of Ukraine : electron. Science. profession. ed. / Head. ed. Gryaznov IA 2012. Vol. 3. - Available from : http://www.nbuv.gov.ua/e-journals/Vnadps/2012_3/12kdanvp.pdf (in Ukrainian).

5. Tryus Y. Information-analytical system of educational management [online] / Tryus, I. Stetsenko, I. Gerasimenko, V. Gritsenko. Information Technologies in Education. - 2011. - Issue 9. - P. 40-49. Available from: http://ite.kspu.edu/en/issue9/p-40-49

6. Glomozda D. K. About one approach to the organization of interaction between the automated system of management of educational institution and system of management of training [online] / D. K. Glomozda. Scientific notes of NaUKMA. Computer science.- 2010. - - Vol. 112. - P. 30-33. - Available from : http://nbuv.gov.ua/UJRN/NaUKMAkn_2010_112_9

7. VV\&LV(dev) - Google Sites [online]. - Available from : https://sites.google.com/site/bulatetsky 